\title{
The Copenhagen Climate Conference It Still Takes Two to Tango
}

\section{When we were 16 or 17 our girlfriends were always keen on} going to a dance but the males were usually very reluctant dancers. By about 10 o'clock two couples would finally make it onto the floor and then everyone would be up for dancing. By 12 o'clock the band would be packing up and everyone would be saying we should have started earlier.

At Copenhagen most of the countries present had a better offer for emission reductions to table, but it needed the United States and China to go onto the dance floor to really get the party going. The US, while offering to help contribute to $\$ 100$ billion a year in assistance from 2020 for least developed countries facing the full impact of climate change, did not move beyond an emissions reduction target of $17 \%$ below 2005 levels by 2020 . This reduction is in the Waxman Markey Bill passed by the House of Representatives in 2009.

One of the first things US climate change negotiator Todd Stern said when appointed was that he would not take a

Peter Neilson is Chief Executive of the New Zealand Business Council for Sustainable Development. He attended the COP15 climate change talks at Copenhagen as a member of the delegation of the World Business Council for Sustainable Development. 'dead letter' agreement back to the United States. US agreement to a climate change treaty requires a two-thirds majority agreement of the US Senate, unless fasttrack approval legislation is passed, as has been done for trade negotiations in the past. When the Kyoto Treaty was negotiated, the US delegation headed by Al Gore raised expectations that the US would be an active participant in reducing emissions. The Clinton administration did not submit the Kyoto Treaty to the Senate because it knew it would not be supported. President Obama's offer to the Copenhagen talks was not so good that it would require China to respond or the European Union and other developed countries to increase their offerings. New Zealand and other countries at Copenhagen were mandated to lift their offerings if a US-China agreement with sufficient ambition was made. The Copenhagen conference came about a year too early for the US administration to know what it could best offer. Therefore, no one else had a reason to put up their best offer.

While Copenhagen was not as successful as it might have been, it did represent some solid progress:

- All of the major emitters were engaged in finding a solution, a big advance on the Kyoto Treaty.

- There was broad agreement that the world should aim at a maximum increase of average global temperatures of $2{ }^{\circ} \mathrm{C}$ (even if the Group of 77 of less developed countries would have preferred $1.5^{\circ}$ ).

- $\$ 100$ billion per year in finance from developed countries to help less developed countries adapt to climate change has been agreed from 2020, along with opening to scrutiny the emission reduction performance of all countries with commitments.

The sting in the tail is that achieving the $25 \%-40 \%$ emission reductions needed to hold temperature rises to the agreed $2{ }^{\circ} \mathrm{C}$ will require all developed countries, including New Zealand, to increase their current emission reduction targets. Current emission cut offers on the table fall 4 billion tonnes short of the level scientists advise will be needed to have only a 50\% chance of achieving the agreed temperature cap.

The biggest change since 2005 is who is now relevant to the debate. Previously it 
was the EU and developing countries. Now, for the first time the US, China, India and Brazil are taking formal responsibilities. The other major emitting bloc, the EU, is also prepared to cut further once the emitting heavyweights make more ambitious reduction commitments.

The reality is that while we have huge sympathy for the issues faced by the less developed nations from climate change, they have little to trade at the table. Developed countries - and the fast developing nations - have the greatest potential to change their emissions profiles and have the biggest share of total emissions.

So what happens now?

- Countries will put their emission cut commitments on the table by 1 February 2010, and list what they are going to do to mitigate and adapt (with these pledges being subject to review, reporting and verification).

- The US emissions trading scheme law will probably pass the US Senate in the first or second quarter of this year - a vital part of securing significant commitments from the major emitting and developing nations, including the US, European Union, China, India and Brazil.

- A more comprehensive world agreement should be negotiated this year, probably in time to be put before the US Senate for ratification after mid-term elections in November. Alternatively, President Obama might get fast-track approval powers, as have been given previous presidents for trade negotiations.

One of the biggest steps which must be taken before the end of 2010 is to persuade senators and congressmen from the US Midwest to increase their ambitions to reduce emissions. President Obama has been careful to move no further than what the US Senate is likely to support. The aim this year is to have a legally binding agreement, ratified by the Senate unless otherwise authorised. While there is considerable enthusiasm for action on climate change on the east and west coasts of the US, each state has two votes in the Senate. The senators from Midwest states, which have a high dependence on coal, agriculture and traditional smokestack industries, will need to persuade their constituents that they will not be adversely affected by an agreement on climate change or the introduction of an emissions trading scheme.

So the debates, in New Zealand and abroad, over the extent of emission cut commitments and how to achieve them, so well canvassed in the past year here, will be had again.Importantly, they are going to take place now within the required context of the agreed global target the scientists tell us is necessary. Through all this New Zealand needs to take care not to lose some significant gains made at Copenhagen.

\section{.. the new global clean- economy market will be very large and potentially very profitable.}

The draft agreement text, although still to be signed, will deliver us the benefits of flexible land use. If the draft text holds - and no one exercises an unforeseen veto - then we will be able to harvest trees planted before 1990 and replant on another site without incurring a carbon penalty. There is also recognition that carbon is embedded in wood products and does not all return to the atmosphere on felling.

Our historical land use flexibility advantage needs to continue. For example, at current meat and wool prices many farmers are finding it more profitable to grow trees. For others it will mean a switch to dairying or other production while replanting forests on marginal land. These proposals are not a potential veto issue at the moment for any of the major players. However, we need to be vigilant to ensure it remains that way, even if wild cards are played by other nations during the negotiations.

So what are the business implications? There will be a huge market in abatement technology to cut emissions in the US, China, India, Brazil, the EU and in the other developed economies. Consumer awareness of the environmental impact of goods and services through the whole supply chain will grow. The US is particularly keen on finding the cheapest possible ways of mitigating and cutting emissions and so will have a reasonably open regime for importing emission reduction offsets from anywhere in the world.

At Copenhagen in December I listened to the US secretary of agriculture speak of agriculture, while responsible for $7 \%$ of the US emissions problem, being a potential source of $20 \%$ of the country's solution. He sees this coming through changes in land use, biosequestration and soil carbon.The New Zealand initiative for a global research partnership to find ways of reducing agricultural emissions offers us the potential for new export industries built around new mitigation and adaptation technologies, such as an inoculation to reduce methane produced by ruminant animals.

Clearly, transport fuels for aircraft and shipping, important to New Zealand, are going to be part of the newglobalagreement - and this will result in businesses striving for greater efficiency, using new technology and more environmentally friendly fuels. Skilful marketing will also be needed. In Copenhagen there were protesters calling for the world to go vegetarian or vegan, claiming this would cause fewer emissions than producing food from animals. While intuitively obvious yet factually wrong, the 'buy local' and 'food miles' campaigns have to be addressed.There is a risk that simplistic slogans will be used to frame the debate, with people thinking 'I care, therefore I'm doing something' if governments do not take action.

However, as a result of the widely supported new agreement, the new global clean-economy market will be very large and potentially very profitable. Herein lies a significant opportunity for government, researchers and business to leverage this together in the national interest. 